\title{
THE DEVELOPMENT OF RESISTANCE OF SALMONELLA TYPHOSA TO THE FATTY ACID SALTS OF STREPTOMYCIN AND DIHYDROSTREPTOMYCIN ${ }^{1}$
}

\author{
By HENRY WELCH, HENRY FISCHBACH, C. W. PRICE, and C. H. SHAFFER
}

(From the Federal Security Agency, Food and Drug Administration, Washington, D. C.)

Since the discovery of streptomycin by Waksman (1) there have been two major problems involved in its clinical use. Streptomycin was shown early to be inherently toxic, causing eighth-nerve damage in relatively low doses, particularly when given over a long period of time. In addition, all organisms sensitive to streptomycin have been shown to develop resistance to it rapidly, and the resistance is not only demonstrable in vitro but in vivo as well. The development of dihydrostreptomycin has partially answered the problem concerning streptomycin toxicity; however, organisms become resistant to dihydrostreptomycin with the same facility and to a simliar degree. In the present study, an attempt has been made to develop salts of streptomycin and dihydrostreptomycin to which organisms either do not develop a resistance or develop resistance less readily than they do to the salts now available.

It has been known for some time that fatty acids or derivatives of fatty acids may influence markedly the development and severity of experimental tuberculosis in animals. Negre, Berthelot, and Bretey (2) were able to retard the appearance of tuberculosis lesions in guinea pigs by the injection of the ethyl esters of a series of fatty acids. Recently, Hedgecock (3) has reported that the oral administration of a diet containing the total fatty acids of cocoanuts also retarded the development of experimental tuberculosis in animals. Some fats and fatty acids, on the other hand, may enhance the development of experimental tuberculosis in animals. Since streptomycin is a base and has the ability to combine with fatty acids, it was thought worthwhile to make compounds of this nature for test purposes.

The fatty acid salts studied, the caprylate, undecylenate, and proprionate salts of both streptomycin and

\footnotetext{
1 Presented at the Second National Symposium on Recent Advances in Antibiotics Research held in Washington, D. C., April 11-12, 1949, under the auspices of the Antibiotics Study Section, National Institutes of Health, Public Health Service, Federal Security Agency.
}

dihydrostreptomycin were prepared by electrodialyzing the sulfates or hydrochlorides to the corresponding bases (4). The streptomycin base collected at the cathode was then titrated to a $\mathrm{pH}$ of $6.5-7$ with the respective fatty acid. For the more insoluble fatty acids this titration was accomplished by the addition of a few drops of ethanol followed by slow addition of the fatty acid with periodic agitation in a high speed Waring Blendor as the desired $\mathrm{pH}$ was approached. The material was finally filtered to remove excess streptomycin fatty acid salt, leaving a saturated filtrate.

The fatty acid salts prepared by this method were tested for inhibition of the growth of 56 species of bacteria representing 17 genera. Included as controls were streptomycin calcium chloride complex and dihydrostreptomycin sulfate. The medium used was yeast beef broth (Difco). The ranges of the minimal inhibitory concentrations for the species in the various genera are tabulated in Table I. It can be readily seen that, as previously reported by Rake et al. (5), various members of the genus Salmonella are more resistant to dihydrostreptomycin than to streptomycin. The species of mycobacteria tested, smegmatis, phlei, and avian, all show a high sensitivity to the salts under study. In some of the genera there exists a wide variation in the sensitivity of the individual species to the same salt. It is apparent also that there is a considerable but less marked difference in the sensitivity of the same species to the different compounds. These differences indicate that the anionic portion of the molecule may affect materially the activity of streptomycin and dihydrostreptomycin against certain strains of bacteria. This is strikingly shown in the next experiment in which all eight salts were tested for their ability to prevent the increase in resistance of a strain of $S$. typhosa shown by previous studies (6) to have the ability of rapidly increasing in resistance to streptomycin. Serial dilutions of the eight salts were made in standard methods broth, $\mathrm{pH} 7.8$ to 8. All dilutions were then inoculated with standard methods broth containing $1 \%$ of a 24 -hour broth culture of $S$. typhosa. These were then in- 
TABLE I

\section{STREPTOMYCIN COMPOUNDS: RANGE OF CONCENTRATION IN Mcg/ml. NECESSARY} TO INHIBIT VARIOUS MICRO-ORGANISMS

\begin{tabular}{|c|c|c|c|c|c|c|c|c|c|}
\hline GENUS & NO. & \multicolumn{4}{|c|}{ STREPTOMYCIN } & \multicolumn{4}{|c|}{ DIHYDROSTREPTOMYCIN } \\
\hline MYCOBACTERIA & 3 & $.04-.15$ & $15-37$ & $.08-.15$ & $.08-37$ & $.15-.37$ & $.08-.15$ & $\begin{array}{l}\text { comallate } \\
.08-37\end{array}$ & $15-37$ \\
\hline $\begin{array}{l}\text { CORYNOBACTERIUM } \\
\text { NEISSERIA } \\
\text { BACILLI }\end{array}$ & $\begin{array}{c}1 \\
1 \\
12\end{array}$ & $\begin{array}{r}.75 \\
.75 \\
.15-250\end{array}$ & .08 & .08 & $75-50$ & 37 & $\begin{array}{c}.75 \\
37-100\end{array}$ & $\begin{array}{r}625 \\
.75 \\
15-100\end{array}$ & \\
\hline $\begin{array}{l}\text { AEROBACTOR } \\
\text { ESCHERICHIA } \\
\text { SALMONELLA }\end{array}$ & $\begin{array}{l}1 \\
4 \\
7\end{array}$ & 12.5 & $\begin{array}{l}6.25 \\
25\end{array}$ & $25-100$ & 12.5 & $\begin{array}{c}6.25 \\
25-50 \\
200-400\end{array}$ & 25 & $\begin{array}{l}3.12 \\
12.5-25 \\
50-200\end{array}$ & \\
\hline $\begin{array}{l}\text { STREPTOCOCCUS } \\
\text { MICROCOCCUS } \\
\text { KLEBSIEULA }\end{array}$ & $\begin{array}{l}2 \\
7 \\
2\end{array}$ & $\begin{array}{l}6.2-125 \\
6.25-50 \\
15-15\end{array}$ & $\begin{array}{l}2.5-100 \\
12.5-25 \\
75-12.5\end{array}$ & $\begin{array}{l}12.5-100 \\
1.5-50 \\
75-25\end{array}$ & \begin{tabular}{|l|}
$6.2-200$ \\
$1.5-50$ \\
$37-25$ \\
\end{tabular} & \begin{tabular}{|l}
$1.5-125$ \\
$3.12-50$ \\
$.15-75$ \\
\end{tabular} & $\begin{array}{l}125-100 \\
75-50 \\
15-12.5\end{array}$ & $\begin{array}{l}12.5-100 \\
75-50 \\
37-12.5 \\
\end{array}$ & $\begin{array}{l}25 \\
75 \\
75\end{array}$ \\
\hline $\begin{array}{l}\text { PSEUDOMONAS } \\
\text { SARCINA }\end{array}$ & 2 & & & $\begin{array}{c}100 \\
37-.75\end{array}$ & $\begin{array}{c}100 \\
37-3.12\end{array}$ & $\begin{array}{l}100-200 \\
.15-1.5\end{array}$ & 100 & $\begin{array}{c}100 \\
08-3.12\end{array}$ & $\begin{array}{c}100 \\
.15-1.5\end{array}$ \\
\hline $\begin{array}{l}\text { BERKAIIA } \\
\text { BRUCELLA } \\
\text { LEUCONOSTOC } \\
\text { CLOSTRIDIUM }\end{array}$ & $\begin{array}{l}3 \\
2 \\
1 \\
4\end{array}$ & $\begin{array}{l}75-100 \\
3.12 \\
50-250\end{array}$ & $\begin{array}{c}75-100 \\
3.12 \\
50-200\end{array}$ & $\begin{array}{l}12.5-50 \\
75-100 \\
3.12 \\
50-200\end{array}$ & $\begin{array}{l}.75-200 \\
.75 \\
50-200\end{array}$ & $\begin{array}{l}.75-200 \\
12.5 \\
31.2-250\end{array}$ & $\begin{array}{l}37-200 \\
3.12 \\
100\end{array}$ & $\begin{array}{l}37-200 \\
3.12 \\
25-100\end{array}$ & $\begin{array}{l}75-20 \\
75 \\
25-20\end{array}$ \\
\hline
\end{tabular}

cubated overnight at $37^{\circ} \mathrm{C}$ and the tube containing the largest concentration of the salt which showed growth was used as the inoculum for the next series of dilutions. This was continued for 22 transfers. In Table II is shown the initial sensitivity of $S$. typhosa to the eight salts, and the sensitivity obtained on the 22nd transfer.

It can be seen that the strain of $S$. typhosa used in these studies increased in resistance to streptomycin calcium chloride complex and to dihydrostreptomycin sulfate to a far greater extent than to the fatty acid salts used. The increase in resistance to streptomycin caprylate and undecylenate was less than with any of the other salts tested.

In order to determine the specificity of the resistance developed, the strains of $S$. typhosa made resistant to the fatty acid salts of streptomycin and to streptomycin calcium chloride complex were tested for their resistance to each of the other salts. For comparative purposes, streptomycin sulfate and streptomycin hydrochloride were included. The results are shown in Table III.

It will be noted that when a strain of $S$. typhosa is made resistant to $5000 \mu \mathrm{g} / \mathrm{ml}$ of the calcium chloride complex salt of streptomycin, its resistance to the fatty acid salts was found to be considerably less. In the case of the undecylenate and caprylate salts, this resistance was less than 100 $\mu \mathrm{g} / \mathrm{ml}$. The propionate salt, which incidentally is the most soluble of the three fatty acid salts studied, caused inhibition of growth of $S$. typhosa at a concentration of $187 \mu \mathrm{g} / \mathrm{ml}$, a somewhat higher level. It was necessary, however, to utilize $625 \mu \mathrm{g} / \mathrm{ml}$ of streptomycin sulfate and $5000 \mu \mathrm{g} / \mathrm{ml}$ of the streptomycin hydrochloride to cause inhibition of $S$. typhosa which had been made resistant to 5000 $\mu \mathrm{g} / \mathrm{ml}$ of the calcium chloride complex salt of streptomycin. Except in the case of the propionate salt, whenever $S$. typhosa was made resistant to

TABLE II

Increase in resistance of $\mathrm{S}$. Typhosa to Fatty acid salts of streptomycin and dihydrostreptomycin

\begin{tabular}{|c|c|c|c|}
\hline \multirow{2}{*}{ Streptomycin salt } & \multicolumn{3}{|c|}{ Minimum inhibition conc. in $\mu \mathrm{g} / \mathrm{ml}^{*}$} \\
\hline & Initial & $\begin{array}{c}\text { After } 22 \\
\text { transfers }\end{array}$ & $\begin{array}{l}\text { Increased } \\
\text { resistance } \\
\text { ratio }\end{array}$ \\
\hline $\begin{array}{l}\text { Caprylate } \\
\text { Propionate } \\
\text { Undecylenate } \\
\mathrm{CaCl}_{2}\end{array}$ & $\begin{array}{l}0.07 \\
0.07 \\
0.07 \\
0.07\end{array}$ & $\begin{array}{r}25 \\
531 \\
62 \\
5,000\end{array}$ & $\begin{array}{r}356 \\
7,600 \\
900 \\
71,000\end{array}$ \\
\hline $\begin{array}{c}\text { Dihydro- } \\
\text { streptomycin } \\
\text { salt }\end{array}$ & Initial & $\begin{array}{c}\text { After } 22 \\
\text { transfers }\end{array}$ & $\begin{array}{c}\text { Increased } \\
\text { resistance } \\
\text { ratio }\end{array}$ \\
\hline $\begin{array}{l}\text { Caprylate } \\
\text { Propionate } \\
\text { Undecylenate } \\
\text { Sulfate }\end{array}$ & $\begin{array}{l}0.62 \\
0.62 \\
0.31 \\
0.62\end{array}$ & $\begin{array}{r}625 \\
1,500 \\
437 \\
5,000\end{array}$ & $\begin{array}{r}1,000 \\
2,420 \\
700 \\
8,000\end{array}$ \\
\hline
\end{tabular}

* Standard Methods Broth pH 7.8-8 used throughout. 
TABLE III

EFFECT OF STREPTOMYCIN SALTS ON RESISTANT S. TYPHOSA

\begin{tabular}{|c|c|c|c|c|}
\hline \multirow[t]{2}{*}{$\begin{array}{r}\text { STREPTOMYCIN } \\
\text { SALT EMPLOYED }\end{array}$} & \multicolumn{4}{|c|}{$\begin{array}{l}\text { MINIMUM CONCENTRATION IN Mcg/ml. NECESSARY TO } \\
\text { INHIBIT SALMONELLA TYPHOSA MADE RESISTANT TO:- }\end{array}$} \\
\hline & $\begin{array}{r}5000 \text { mca/mil. } \\
\text { CoCl2 COMPLEX }\end{array}$ & $\begin{array}{c}30 \mathrm{mcg} / \mathrm{ml} . \\
\text { UNDECYLENATE }\end{array}$ & $\begin{array}{r}80 \mathrm{mcg} / \mathrm{ml} . \\
\text { CAPRYLATE }\end{array}$ & $\begin{array}{l}\text { 400mcg/ml. } \\
\text { PROPIONATE }\end{array}$ \\
\hline $\mathrm{CaCl}_{2}$ COMPLEX & & 625 & 625 & 312 \\
\hline UNDECYLENATE & 62 & & 31 & 62 \\
\hline CAPRYLATE & 94 & 78 & & 312 \\
\hline PROPIONATE & 187 & 110 & 110 & \\
\hline SULFATE & 625 & 312 & 312 & 312 \\
\hline HYDROCHLORIDE & 5000 & 625 & 625 & 312 \\
\hline
\end{tabular}

the fatty acid salts these organisms were always found to be considerably more resistant to the streptomycin salts commercially available. It is of interest that an organism made resistant to $5000 \mu \mathrm{g} / \mathrm{ml}$ of the calcium chloride complex salt of streptomycin, although showing the same resistance to streptomycin hydrochloride, was found to have a resistance to only $625 \mu \mathrm{g} / \mathrm{ml}$ of streptomycin sulfate. These results, coupled with those obtained with the fatty acid salts, support the conclusion that the anionic portion of the streptomycin and dihydrostreptomycin molecules may markedly influence the development of resistance of organisms to these drugs.

In order to determine the acute intravenous toxicity of the six fatty acid salts under study,

TABLE IV

Acute intravenous toxicity of various salts of streptomycin and dihydrostreptomycin

\begin{tabular}{|c|c|c|}
\hline Streptomycin salt & $\begin{array}{c}\mathrm{LD} 50 \\
\begin{array}{c}\mu \mathrm{g} / 20 \mathrm{gm} \\
\text { mouse }\end{array}\end{array}$ & $\begin{array}{l}\text { Solubility } \\
\text { in } \mathrm{H}_{2} \mathrm{O}\end{array}$ \\
\hline $\begin{array}{l}\text { Calcium chloride complex } \\
\text { Caprylate } \\
\text { Undecylenate* } \\
\text { Propionate }\end{array}$ & \multirow[t]{2}{*}{$\begin{array}{l}3350 \\
1720 \\
1860 \\
2025\end{array}$} & \multirow[t]{2}{*}{$\begin{array}{c}m g / m l \\
\text { Very soluble } \\
8.8 \\
2.5 \\
\text { Very soluble }\end{array}$} \\
\hline Dihydrostreptomycin salt & & \\
\hline $\begin{array}{l}\text { Sulfate } \\
\text { Caprylate } \\
\text { Undecylenate† } \\
\text { Propionate }\end{array}$ & $\begin{array}{l}2700 \\
1920 \\
2010 \\
2600\end{array}$ & $\begin{array}{c}\text { Very soluble } \\
8.8 \\
2.5 \\
\text { Very soluble }\end{array}$ \\
\hline
\end{tabular}

* Saline used as diluent.

$\uparrow$ Total of $2 \mathrm{ml}$. injected in saline solution. the LD50 of each was determined in 20-gm. mice. For control purposes, the calcium chloride complex salts of streptomycin and dihydrostreptomycin sulfate were similarly tested. The results and also solubility data are tabulated in Table IV where it will be noted that the fatty acid salts of streptomycin are all of the same order of toxicity, approximately $1700-2000 \mu \mathrm{g} / 20$-gm. mouse, in contrast to $3350 \mu \mathrm{g} / 20 \mathrm{-gm}$. mouse for the calcium chloride complex salt. Similar figures (approximately $2000 \mu \mathrm{g} / 20$-gm. mouse) were obtained for the caprylate and undecylenate salts of dihydrostreptomycin, while the toxicity of propionate salt of dihydrostreptomycin was of the same order of toxicity as dihydrostreptomycin sulfate.

\section{DISCUSSION}

It is apparent from the present study that the bacterial spectra of the fatty acid salts of streptomycin and dihydrostreptomycin are approximately the same as those for the presently available commercial salts of these drugs. The genera of those organisms susceptible to the commercially available salts were found to be equally susceptible to the fatty acid salts of streptomycin and dihydrostreptomycin, respectively. The individual species of bacteria which were found to have a low resistance to the commercially available streptomycin were found to have a similar low resistance to the fatty acid salts of this drug. Those found to have a high resistance to commercially available streptomycin (e.g. Salmonella) were found to have a 
similar resistance to the fatty acid salts of streptomycin. A similar pattern was demonstrated with dihydrostreptomycin sulfate and the fatty acid salts of dihydrostreptomycin.

When attempts were made to demonstrate the increase in resistance of a strain of $S$. typhosa to the fatty acid salts of streptomycin and dihydrostreptomycin, using as controls the calcium chloride complex salt of streptomycin and dihydrostreptomycin sulfate, it was quite obvious that this organism developed resistance to a considerably less degree to the fatty acid salts than to the commercially available salts of streptomycin and dihydrostreptomycin.

Studies of resistant strains of $S$. typhosa developed through growth in increasing concentrations of the various salts of streptomycin indicate that the resistance developed is specific to a certain degree. A strain of $S$. typhosa made resistant to $5000 \mu \mathrm{g} / \mathrm{ml}$ of the calcium chloride complex salt of streptomycin, although having the same resistance to streptomycin hydrochloride, had only one-eighth as much resistance to streptomycin sulfate, less than one-fiftieth the resistance to the caprylate and undecylenate salts of streptomycin, and approximately one-twenty-fifth the resistance to the propionate salt. Twenty-two transfers of $S$. typhosa in increasing concentrations of the undecylenate, caprylate, and propionate salts of streptomycin resulted in the development of resistance of $30 \mu \mathrm{g} / \mathrm{ml}, 80 \mu \mathrm{g} / \mathrm{ml}$ and $400 \mu \mathrm{g} / \mathrm{ml}$, respectively, indicating that the resistance of $S$. $t y$ phosa to these salts develops with some difficulty as compared to the resistance developed by this organism when grown in increasing concentrations of the calcium chloride complex salt of streptomycin. It should be pointed out also that when $S$. typhosa is made resistant to the undecylenate and caprylate salts of streptomycin, the resistance developed concomitantly to the streptomycin salts commercially available is considerably greater. Thus, a strain of $S$. typhosa made resistant to 30 $\mu \mathrm{g} / \mathrm{ml}$ of the undecylenate salt of streptomycin was found to be resistant to from 312 to $625 \mu \mathrm{g} /$ $\mathrm{ml}$ of streptomycin sulfate, streptomycin hydrochloride, and the calcium chloride complex salt of streptomycin. Since in these studies an intensive effort was made to increase the resistance of a strain of $S$. typhosa to the various streptomycin salts utilized, it is quite possible that under ordinary conditions little or no resistance would develop to the fatty acid salts. The results of these studies indicate the preparation of new streptomycin and dihydrostreptomycin compounds might well lead to the finding of drugs with improved usefulness. The fatty acid salts are being tested for their effect on experimental infections in animals and for their inhibitory action against tubercle bacilli isolated from cases treated with commercially available salts of streptomycin and dihydrostreptomycin.

It is apparent from the acute toxicity studies of the fatty acid salts of streptomycin and dihydrostreptomycin that the fatty acid salts of streptomycin have approximately twice the acute toxicity of the calcium chloride complex salt of streptomycin, while the propionate salt of dihydrostreptomycin has approximately the same toxicity as dihydrostreptomycin sulfate, and the caprylate and undecylenate salts of dihydrostreptomycin have only a slightly greater toxicity than dihydrostreptomycin sulfate. It should be pointed out that some difficulty was encountered in determining the acute intravenous toxicity because of the insolubility of the caprylate and undecylenate salts of both streptomycin and dihydrostreptomycin.

\section{SUMMARY AND CONCLUSIONS}

1. The bacterial spectra of the fatty acid salts of streptomycin and dihydrostreptomycin are approximately the same as that of the streptomycin and dihydrostreptomycin salts commercially available.

2. S. typhosa develops resistance to the fatty acid salts of streptomycin and dihydrostreptomycin at a slower rate and to a considerably less degree than to the commercially available salts of these drugs.

3. When $S$. typhosa is made resistant to high concentrations of the calcium chloride complex salt of streptomycin, this organism has relatively low resistance to the fatty acid salts of streptomycin, and, conversely, when $S$. typhosa is made resistant to relatively low concentrations of the fatty acid salts of streptomycin, this organism has a relatively high resistance to the commercially available salts of streptomycin. 
4. The anionic portion of the streptomycin and dihydrostreptomycin molecules markedly affects the ability of an organism to develop resistance to these drugs.

5. The fatty acid salts of streptomycin studied are from 1.5 to 2.0 times as toxic as the calcium chloride complex salt of streptomycin when tested intravenously in mice, while the fatty acid salts of dihydrostreptomycin are of approximately the same order of toxicity as dihydrostreptomycin sulfate.

\section{BIBLIOGRAPHY}

1. Schatz, A., Bugie, E., and Waksman, S. A., Streptomycin, a substance exhibiting antibiotic activity against gram-positive and gram-negative bacteria. Proc. Soc. Exper. Biol. \& Med., 1944, 55, 66.
2. Negre, L., Berthelot, A., and Bretey, J., Sur l'action retardante exercée par les esters éthyliques de certains acides gras saturés sur l'évolution de la tuberculose expérimentale du cobaye. Ann. Inst. Past., 1937, 59, 457.

3. Hedgecock, L. W., Influence of dietary lipids on experimental tuberculosis. Proc. Soc. Exper. Biol. \& Med., 1940, 68, 106.

4. Fischbach, H., Electrodialysis in the field of antibiotics. Jour. Amer. Pharm. Assoc., Scient. Ed., 1948, 37, 470.

5. Rake, G., Pansy, F. E., Jamnor, W. P., and Donovick, R., Further studies on the dihydrostreptomycin. Amer. Rev. Tub., 1948, 58, 470.

6. Price, C. W., Randall, W. A., Chandler, V. L., and Reedy, R. J., Observations on the in vivo and in vitro development of bacterial resistance to streptomycin. Jour. Bact., 1947, 53, 481. 